Кулик В. В., к.е.н., старший науковий співробітник ДННУ «Академія фінансового управління» м. Київ, Украӥна

DOI: https://doi.org/10.30525/978-9934-26-123-7-9

\title{
МОДЕЛЮВАННЯ РОЗВИТКУ ЕКОНОМІКИ ЯК СУКУПНОСТІ ОБ'СКТІВ КРИТИЧНОЇ ІНФРАСТРУКТУРИ: ПРИКЛАД АГРЕГОВАНОЇ МОДЕЛІ ЛЕОНТЬЕВА ДЛЯ ЕКОНОМІКИ ПОЛЬЩІ
}

\begin{abstract}
Національну економіку слід розглядати як критичну інфраструктуру, що представлена системою дуальних протиставлень - «попит» i «пропозиція», «споживачі» i «виробники», «кінцеві продукти» і «отримувані доходи» тощо. Всі вони тісно пов'язані поміж собою - пропозиція формується внаслідок попиту, виробники відгукуються на потреби споживачів, загальна вартість кінцевих товарів споживаних споживачами відповідає сукупному доходу отримуваному виробниками. Вказані суб'єкти економіки можуть бути представлені в рамках окремих продуктів, продуктових груп, підгалузей і галузей економіки, укрупнених секторів (агросектор, промисловість, сфера послуг); вони взаємодіють в процесах виробництва кінцевого продукту, його розподілу і споживання.

В умовах ринкової економіки - нестабільності зумовленої внутрішніми і зовнішніми чинниками - важливо
\end{abstract}


підтримувати умови стабільності такої системи, пї передбачуваності, внутрішньої збалансованості, зменшення ризиковості їі функціонування тощо.

Для моделювання взаємовпливів між «споживачами» $\mathrm{i}$ «виробниками» застосовують модель Леонтьєва (відому як модель «витрати-випуск») [1]. Зауважимо, модель Леонтьєва має дві інтерпретації - вплив витрат «виробників» на випуск (прямі витрати) та вплив витрат «спожсивачів» на обсяги випуску (обернені витрати). Тобто вона уможливлює моделювання прямих і обернених зв'язків в багатогалузевій економічній системі; проте їі повноцінне застосування накладає певні умови на систему - взаємоузгодження дій «споживачів» та «виробників» на основі спільних цінностей, що забезпечують довіру, стабільність цін, конкурентний відбір на етапах виробництва та формування попиту на кінцеві товари, формування такої структури ВВП, шо гарантує стабільність (або наближає до неї). I саме головне - постійна оптимізація структури виробничих витрат в спосіб, що зменшує матеріаломісткість i енергомісткість виробленого продукту, наближає його до вуглецевої нейтральності тощо.

Для цього необхідне застосування інструментів макроекономічного аналізу і моделювання - таблиці витративипуск і відповідного методу.

Моделювання прямих зв'язків при процесах виробництва здійснюється за допомогою моделі Леонтьєва:

$$
X=A X+Y, X \geq 0,
$$

де $X$ - випуск, $A X$ - проміжне споживання, $Y$ кінцевий продукт, $A$ - матриця прямих витрат. 
Моделювання обернених зв'язків при процесах споживання кінцевого продукту дає відповідь на питання яким чином збільшення споживання кінцевого продукту на одиницю впливає на обсяги випуску - i описується за допомогою модифікованої моделі Леонтьєва, що випливає 3 (1):

$$
X=Y(I-A)^{-1},
$$

де $(I-A)^{-1}$ - обернена матриця Леонтьєва.

При розгляді економіки як одно-галузевого утворення моделювання прямих і обернених зв'язків є тривіальним; у випадку багатогалузевої взаємодії моделювання ускладнюється і не є настільки очевидним, особливо в частині моделювання обернених міжгалузевих зв'язків.

Розглянемо таблицю витрати-випуск Польщі (2015 р.), представлену трьома секторами економіки (I агросектор, II промисловість, III сфера послуг), і застосування методу (табл. 1-3).

Для одно-галузевого варіанту матриця витрат А записується як скаляр i його значення становить 0,53823 . Відповідно збільшення споживання кінцевого продукту $Y$ на одиницю зумовлює зростання випуску $X$ на 2,16558= 1/(1-0,53823). Для багато-галузевого варіанту матриця витрат А (табл. 2) випливає із таблиці витрати-випуск (табл. 1) і $є$ цілком зрозумілою. Проте моделювання обернених зв'язків потребує знаходження оберненої матриці Леонтьєва (табл. 3), яка визначається математичними методами і значення елементів якої не $є$ настільки наочним як у попередньому випадку. 
Таблиця 1

ТВВ в основних цінах. Польща, 2015 р., млн. Zl.

\begin{tabular}{|c|c|c|c|c|c|c|}
\hline & I & II & III & $\Sigma$ & ВВП ${ }^{1}$ & Випуск \\
\hline I & 19102,8 & 57766,7 & 4417,3 & 81286,8 & 33649,7 & 114936,5 \\
\hline II & 34819,5 & 814639,7 & 257958,1 & 1107417,4 & 581041,3 & 1688458,6 \\
\hline III & 14118,7 & 266088,7 & 460830,1 & 741037,5 & 1040911,4 & 1781948,9 \\
\hline$\Sigma$ & 68041,0 & 1138495,2 & 723205,6 & 1929741,7 & 1655602,3 & 3585344,0 \\
\hline $\mathrm{BB}^{2,3}$ & 46895,6 & 549963,5 & 1058743,3 & 1655602,3 & & \\
\hline ппуск & 114936,5 & 1688458,6 & 1781948,9 & 3585344,0 & & \\
\hline
\end{tabular}

Примітка: ВВП ${ }^{1}$ - ВВП за категоріями кінцевого споживання, $\mathrm{BBП}^{2}-$ ВВП за виробничим методом, ВВП ${ }^{3}$ - ВВП за категоріями доходу.

Джерело: підготовлено автором на основі [2].

Таблиця 2

Виробництво. Структура витрат (матриця А).

Польща, 2015 р.

\begin{tabular}{|c|c|c|c|c|}
\hline & I & II & III & $\Sigma$ \\
\hline I & 0,16620 & 0,03421 & 0,00248 & 0,02267 \\
\hline II & 0,30295 & 0,48248 & 0,14476 & 0,30887 \\
\hline III & 0,12284 & 0,15759 & 0,25861 & 0,20669 \\
\hline$\Sigma$ & 0,59199 & 0,67428 & 0,40585 & 0,53823 \\
\hline $\mathrm{BB \Pi}^{2}$ & 0,40801 & 0,32572 & 0,59415 & 0,46177 \\
\hline Випуск & 1 & 1 & 1 & 1 \\
\hline
\end{tabular}

матриця A

Таблиця 3

Матриця Леонтьева виду B=(I-A) $)^{-1}$, Польща, 2015 p.

\begin{tabular}{|c|ccc|}
\hline & I & II & III \\
\hline I & 1,23449 & 0,08811 & 0,02133 \\
II & 0,82915 & 2,11360 & 0,41547 \\
III & 0,38079 & 0,46387 & 1,44067 \\
\hline
\end{tabular}

матриця

повних

витрат 
Обернену матрицю Леонтьєва $\mathrm{B}=(\mathrm{I}-\mathrm{A})^{-1}$ називають також матрицею повних витрат, використання якої дає відповіді на питання яким чином зміниться галузевий випуск залежнн від зростання кінцеевого спожсивання галузі на одиницью.

Для Польщі $\epsilon$ справедливим: зростання обсягів кінцевого продукту в агросекторі на 1000 злотих зумовлює зростання випуску агросектору на 1234,49 злотий, промисловості - на 829,15 злотий, сфери послуг - на 380,79 злотий; випуск економіки в цілому зросте на 2444,42 злотий. Аналогічні обчислення справедливі і для інших секторів. Порівнюючи зростання обсягів кінцевого продукту по секторах на 1000 злотих, визначаємо той сектор, що генерує найбільший за обсягом випуск. Ним є промисловість, яка генерує додатково 2665,58 злотих випуску.

Аналіз, проведений щодо економіки Польщі, можна i необхідно поширити на інші економічні системи. В роботі [3] приведено вихідні агреговані (три-секторні) таблиці «витрати-випуск» для економік Німеччини, Великобританії, Японії, Польщі та вихідні дані - матриці виробничих витрат (матриця А) та обернені відповідні матриці Леонтьєва. Приведено інші похідні обчислення - визначення структури випуску і ВВП, класифікація секторів за їх впливом на економіку та ін.

Викладений вище підхід не $\epsilon$ новим. Проте надзвичайно важливим $є$ проведення параметризації моделі для конкретного випадку (три-секторна модель Леонтьєва для економіки Польщі, 2015 р.) та аналіз на її основі. Це також важливо з точки зору формування суспільства знань [4] i 
поширення загальновідомих наукових ідей на облаштування циркулярної економіки і моделювання процесів іï функціонування.

В даній роботі проведена параметризація трисекторної моделі Леонтьева для економіки Польщі. Розглянута взаємодія «споживачів» та «виробників» в процесах економічного кругообігу. Економіка розглянута як сукупність об’єктів критичної інфраструктури, моделювання розвитку якої здійснюється на основі прямих i обернених зв'язків.

Приведений аналіз вказує на важливість: 1) упорядкування фінансування витрат кінцевого споживання 3 точки зору впливу на обсяги випуску в секторах; 2) сприяння виробництву і підтримка конкуренції в процесах виробництва задля зменшення виробничих витрат (елементів матриці А) та збільшення галузевих доходів/доданої вартості сектору; 3) упорядкування (взаємопогодження) доходів фізичних осіб зайнятих у виробничій і невиробничій сферах; 4) суттєве підвищення відрахувань на амортизацію капіталу в секторах економіки задля підвищення та утримування інвестиційного попиту на задовільному рівні; 5) упорядкування тарифів та ціноутворення задля стабілізації ринків та недопущення несправедливого перерозподілу виробничих доходів та ін.

Економічні реформи - це якісне поліпшення структури виробничих витрат (матриці А) та зменшення їх обсягів. Власне приватизація державних підприємств, яку можна розглядати як одну із форм децентралізації, i була покликана розвинути національне виробництво, підвищити 
його конкурентоспроможність і продуктивність, належним чином перерозподілити доходи задля підтримки економічного росту і стабільності.

\section{Література:}

1. Леонтьев В.В. Избранные произведения : в 3т. / науч. ред., вступ. ст. А.Г. Гранберга. Москва : Экономика, 2006-2007. Т. 1. 2006. 407 c.; T. 2. 2006. 543 c.; T. 3. 2007. 407 c.

2. Bilans przepływów międzygałęziowych w bieżących cenach bazowych w 2015 roku. URL: https://stat.gov.pl/obszary-tematyczne/ rachunki-narodowe/roczne-rachunki-narodowe/bilans-przeplywow-miedzygaleziowych-w-biezacych-cenach-bazowych-w-2015-roku,7,3.html.

3. Кулик В.В. Критична інфраструктура в системі виробничих і фінансово-економічних взаємозв'язків «витрати-випуск». Фінанси Украӥни. 2021. № 6. С.89-108.

4. К обществам знания: Всемирный доклад ЮНЕСКО. Париж, $2005.231 \mathrm{c}$. 